\title{
CAMBIAL ACTIVITY AND RADIAL GROWTH DYNAMICS OF THREE TROPICAL TREE SPECIES AT GHANG ISLAND, THAILAND
}

\author{
Pumijumnong $\mathrm{N}^{1}$ *, Danpradit $\mathrm{S}^{1}$, Tadang $\mathrm{N}^{1}$, Buajan $\mathrm{S}^{1}$ \& Muangsong $\mathrm{C}^{2}$ \\ ${ }^{1}$ Faculty of Environment and Resource Studies, Mahidol University, Nakhon Pathom 73170 Thailand \\ ${ }^{2}$ Innovation for Social and Environmental Management, Mahidol University, Amnatcharoen Campus, Amnatcharoen \\ 37000 Thailand \\ *nathsuda@gmail.com
}

Submitted January 2019; accepted April 2019

\begin{abstract}
The cambial activity and radial growth of three tropical species, Tetrameles nudiflora, Hopea pierrei and Cleidion spiciflorum at Chang Island were measured monthly from December 2011 to May 2012 and bi-monthly from June to November 2012. We installed electronic dendrometers to analyse stem diameter variation. Cambial activity was quantified by counting the layers of undifferentiated cells in the cambial zone at 10 randomly chosen positions. The relationships between the cambial activity and climatic factors, i.e. rainfall, temperature, relative humidity and soil moisture were investigated by Pearson's correlation. The number of cambial layers was significantly correlated with relative humidity. Growth dynamics of the three species differed considerably. The cambium of T. nudiflora appeared active year-long and was most active at the end of August. Cambial activity for H. pierrei and C. spiciflorum was highest at the end of June and July respectively, but was not significantly correlated with climate. Radial growth measurements showed that all three species contracted in the afternoon from 2.30-6.00 p.m., and the maximum enlargement occurred before 9 a.m. In this rainforest with high rainfall trees grow year-round, and radial growth rate depended on the water cycle rather than the weather conditions in the area.
\end{abstract}

Keywords: Cambial layers, Hopea pierrei, Cleidion spiciflorum, Tetrameles nudiflora, tropical monsoon climate, radial increment, diurnal, seasonal

\section{INTRODUCTION}

Climate change has an impact on tree growth. Climatic factors such as variation in annual and seasonal rainfall influence growth at the level of populations that affect all individuals in a roughly equivalent fashion even though individual- and species-level responses may vary widely (Clark \& Clark 1994). The study of tree growth is needed to understand tree growth and ageing, as well as the factors controlling tree growth. The study of cambial activity is one of the methods of determining which tree species makes clear annual rings or, in other words, this method can estimate the age of trees.

Tropical tree species vary greatly in growth rate, as influenced by climatic factors that include temperature and rainfall. It is important to understand what drives tree growth at the species-level in order to predict forest dynamics and carbon storage, but species-specific growth responses to these factors are largely unknown for tropical trees. In the humid tropics, seasonal change in environmental conditions may be less pronounced than in temperate forests, but the monsoons bring wet and dry seasons that influence tree growth patterns. High-resolution electronic dendrometers are frequently used to measure stem diameter variation over finer time scales and to record temporal growth relevant to cambial cell division and expansion studies (Bräuning et al. 2008, Krepkowski et al. 2012). Data from dendrometer bands installed permanently on 10 tropical tree species in South Brazil revealed a marked seasonality in cambial activity and stem growth associated with high temperatures and long summer days (Shimamoto et al. 2016). Cambial activity has been studied in subtropical forest trees, e.g. teak (Rao \& Dave 1981, Priya \& Bhat 1999, Rao \& Rajput 1999) and acacia in India (Rao \& Rajput 2001b), as well as Azadirachta indica in India (Rao \& Rajput 2001a) and Malaysia (Wang \& Hamzah 2018). In central Thailand, cambial activity was studied for 
Tetrameles nudiflora, Magnolia baillonii, Canarium euphyllum, Toona ciliata and Spondias axillaris growing in a seasonally wet, evergreen, inland tropical forest (Pumijumnong \& Buajan 2013). Cambial activity of trees growing in a tropical monsoon climate has not yet been studied. Chang Island has a tropical monsoon climate with little variation in temperature throughout the year, but due to the influence of the monsoon, varies considerably in precipitation from season to season.

The objectives of the study were to determine the extent to which radial growth and cambial activity of tropical rainforest tree species are influenced by seasonal variation in temperature and rainfall of a tropical monsoon climate. For this study, three tree species were selected that were dominant species on Chang Island i.e. T. nudiflora (Datiscaceae), Hopea pierrei (Dipterocarpaceae) and Cleidion spiciflorum (Euphorbiaceae). Tetrameles nudiflora grows at altitudes from $0-1200 \mathrm{~m}$ asl. The grey bark is thick and smooth. It flowers from March to April, and the fruits mature from April to May (Gardner et al. 2000). It is used as a traditional medicine to treat insect stings, rheumatism, edema and ascites, and as a laxative and diuretic (Prasad et al. 2008). Tetrameles nudiflora and H. pierrei are threatened and endangered species respectively (IUCN 2012). Hopea pierrei is a small dipterocarp tree (20-40 m tall, 60-80 cm diameter at breast height (dbh)) found mainly in lowland evergreen rainforests of Indo-China. The bark is black with deep vertical cracks. The dark grey leaves are eggshaped and coated with a white powder. Cleidion spiciflorum grows up to $30 \mathrm{~m}$ high with a dbh of up to $50 \mathrm{~cm}$. It is a medicinal plant (Menkham 2001). Its stems and roots are used locally to relieve fever and as a remedy for malaria, while the bark serves as a cure for skin diseases and stomach ache (Naengchomnong et al. 2006).

\section{MATERIALS AND METHODS}

\section{Study site}

The study site $\left(12^{\circ} 05^{\prime} \mathrm{N}\right.$ and $\left.102^{\circ} 21^{\prime} \mathrm{E}\right)$ is located on Chang Island (Figure 1), which is

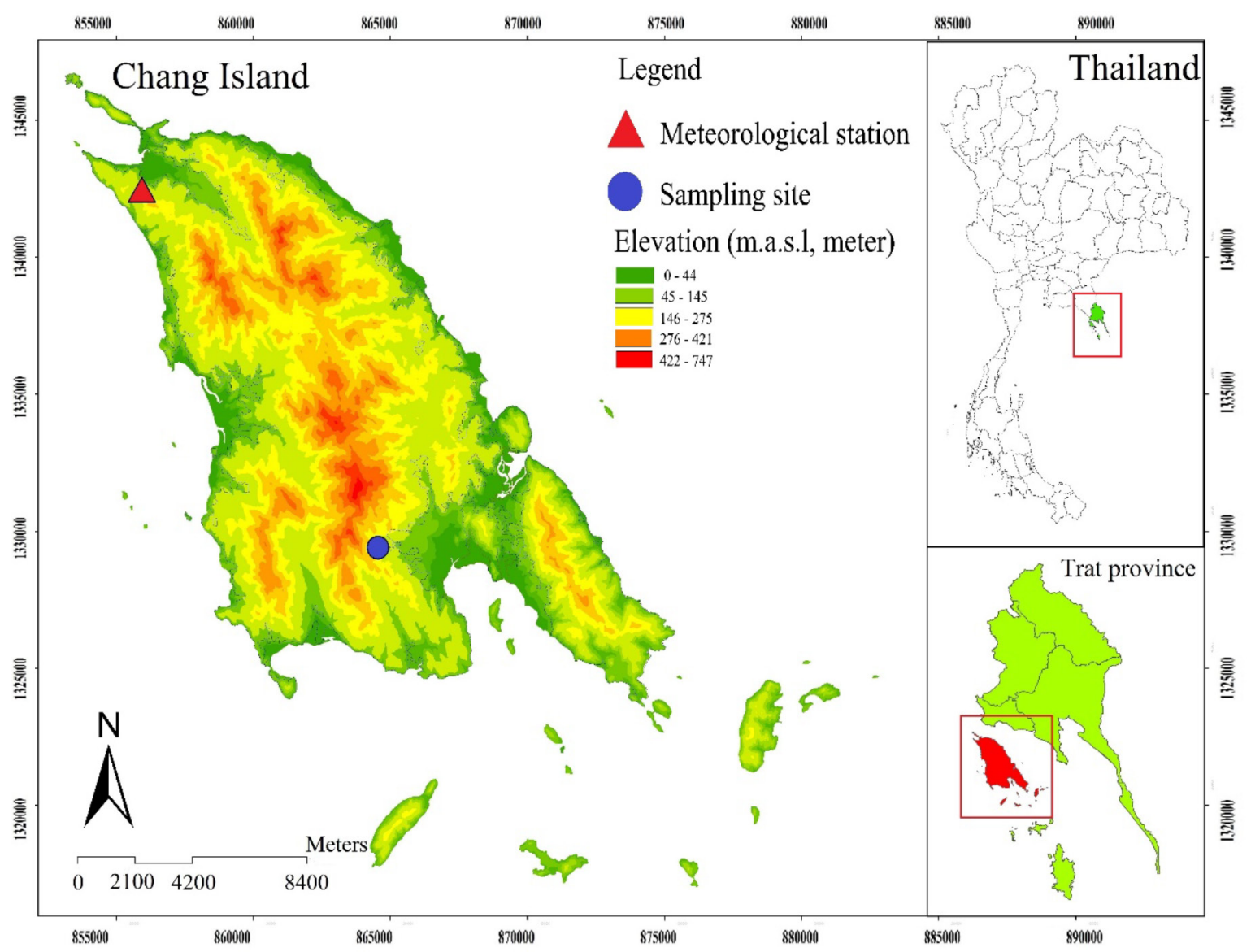

Figure 1 Map of Chang Island showing the sampling site 
part of Mu Koh Chang National Park, a national marine park in Trat Province on the Gulf of Thailand. The total area of Chang Island covers $212.4 \mathrm{~km}^{2}$. There are small mangrove forests around the island and an abundance of plantslargely tropical rainforest species (Pumijumnong \& Payomrat 2013). At Chang Island, T. nudiflora, H. pierrei and C. spiciflorum are dominant species that appear as large emergent plants along canals, streams or foothill slopes around the island.

The rainy season (May-October) is influenced by the south-west monsoon and the dry season (November-April), by the north-east monsoon. Mean annual rainfall is $403.82 \mathrm{~mm}$ and mean annual temperature is $26.7^{\circ} \mathrm{C}$ with annual average minimum and maximum temperatures of 25.4 and $28.0{ }^{\circ} \mathrm{C}$ respectively (Thai Meteorological Department 2010). Soil moisture is $21.87 \%$ with an average minimum and maximum of 5.4 and $32.5 \%$ respectively.

\section{Environmental data}

Soil moisture was measured at 10-cm soil depth. Microclimatic parameters (air temperature and relative humidity) were measured using racing weather tracker. Rainfall was recorded daily using rain gauge installed about $28 \mathrm{~km}$ from the study site.

\section{Tree species}

\section{Sample collection and treatment}

At the study site, three trees of each of the three species were randomly selected and their $\mathrm{dbh}$ measured. The average dbh of T. nudiflora, $H$. pierrei and C. spiciflorum were $153 \pm 0.24,117 \pm$ 0.87 and $143 \pm 0.45 \mathrm{~cm}$ respectively. Tree ages were unknown for all sampled individuals. Sampling was conducted from the same tree once a month from December 2011 till May 2012 and twice a month from June till November 2012 after the installation of electronic point dendrometers. One block measuring approximately $2 \mathrm{~cm} \times$ $2 \mathrm{~cm} \times 1 \mathrm{~cm}$ and containing inner bark, cambium and xylem was removed from the trunk at breast height using a cutter and chisel. Samples were immediately fixed in 3\% glutaraldehyde to preserve cell fine structure. At the laboratory, the samples were dehydrated in a graded series of ethanol (30, 50, 70, 90 and $100 \%)$, soaked for about 2 weeks in polyethylene glycol (PEG) 1500 at $55{ }^{\circ} \mathrm{C}$ then embedded with fresh PEG 1500 for another 24 hours (Holtham \& Slepecky 1995). The samples were then embedded using stainless steel molds and placed in the freezer for at least 24 hours. Transverse sections were cut to a thickness of 15-20 $\mu \mathrm{m}$ using microtome. These sections were stained for light microscopy with safranin and fast green dissolved in xylene, and mounted in permount. The red colour of safranin shows the presence of lignin in the cell walls of xylem cell, and fast green is an indicator for cellulose.

\section{Determination of cambial activity}

The sections were analysed and photographs taken with a stereo microscope. Cambial activity was determined by counting the number of undifferentiated cell layers between mature xylem and phloem in the radial direction of transverse sections at 10 randomly chosen positions along the circumference of the cambium ring. Ten counted values from each side of the tree were used to calculate maximum, median and minimum cambial activity rates.

\section{Electronic dendrometer measurement}

We installed the electronic point dendrometers in May 2012 on two T. nudiflora trees, one $H$. pierrei tree and one C. spiciflorum tree. Two sensors were installed at about $1.5 \mathrm{~m}$ height on opposite sides of each tree to measure changes in stem diameter. Displacement measurements were registered automatically at 30 -min intervals. Data were downloaded every 2 weeks when cambium block samples were taken. Raw data was downloaded from the data logger to the computer using HOBOware Pro version 3.2.1 and converted to $\mu \mathrm{m}$ following the instruction manual for the device. Calculation of the rate of radial variation was modified from Downes et al. (1999) and Deslauriers et al. (2003). These authors prescribed three distinct phases of stem radial variation over a 24-hour period, i.e. contraction (shrinkage), recovery and increment. Additionally, hourly diurnal radial variation in response to rainfall was examined for $2^{\text {nd }}$ and $28^{\text {th }}$ September 2011, which were days of little $(50.6 \mathrm{~mm})$ and abundant $(2059 \mathrm{~mm})$ rainfall respectively. 


\section{Statistical analyses}

All statistical analyses were performed using SPSS 16.0 (2007). Correlations between monthly average values of cambial cell layers and cumulative radial growth $(\mu \mathrm{m})$ and mean, minimum, maximum daily air temperature, total monthly rainfall and soil moisture were evaluated by Pearson's correlation for December 2011 till May 2012. Pearson's correlation was also run with bi-monthly values of cambial layers and cumulative radial growth $(\mu \mathrm{m})$ against bimonthly mean values for weather variables from June till November 2012.

\section{RESULTS AND DISCUSSION}

Rainfall was low during the dry season months of December through April (the driest and hottest month). The wet season months of May through October saw alternating months of low and high rainfall that peaked in September then dropped in October, which was the second hottest month that year. Soil moisture to some extent followed rainfall patterns but showed less fluctuation and remained stable in the wet season even as rainfall recorded alternating high and low months (Figure 2).

\section{Seasonal cambial activity}

In general, cambial activity for the three species tended to positively correlate with rainfall soil moisture and relative humidity (Figure 2) indicating that cambial activity was limited by water availability, but these correlations were not statistically significant (Table 1), except for $T$. nudiflora where cambial activity had significant positive correlation with relative humidity $(\mathrm{r}=0.645, \mathrm{p}<0.01$, Table 1$)$. Cambial activity did not correlate with temperature in this study. Following the May rains at the start of the wet season, cambial activity peaked first for C. spiciflorum in June, followed by $H$. pierrei in July while T. nudiflora cambial activity peaked in August (Figure 2). The peaks in cambial activity were followed by gradual decreases through the wet season and dropped to a low from the start of the dry season in November.

A closer examination of wood anatomical microsections taken monthly for the three species showed that their cambial zones appeared active throughout the year as indicated by swelling fusiform cambial cells (Figures 3-5). This year-round growth was reflected in the monthly cambial layer counts for all three species. Hopea pierrei showed the highest cambial activity through the wet and dry seasons and also overall, followed by T. nudiflora and C. spiciflorum with an overall average cambial layer count of $2.3 \pm 1.8,1.7 \pm 1.3$ and $0.9 \pm 0.8$ respectively. There was an evident seasonality in cambial activity with a tendency towards an increase in cell numbers during the wet season and a decrease during the dry season. Peak cambial activity $(8.2 \pm 1.1$ layers counted in mid-August) in T. nudiflora was not as high as that seen in $H$. pierrei $(12.9 \pm 3.0$, end-July), but mean cambial

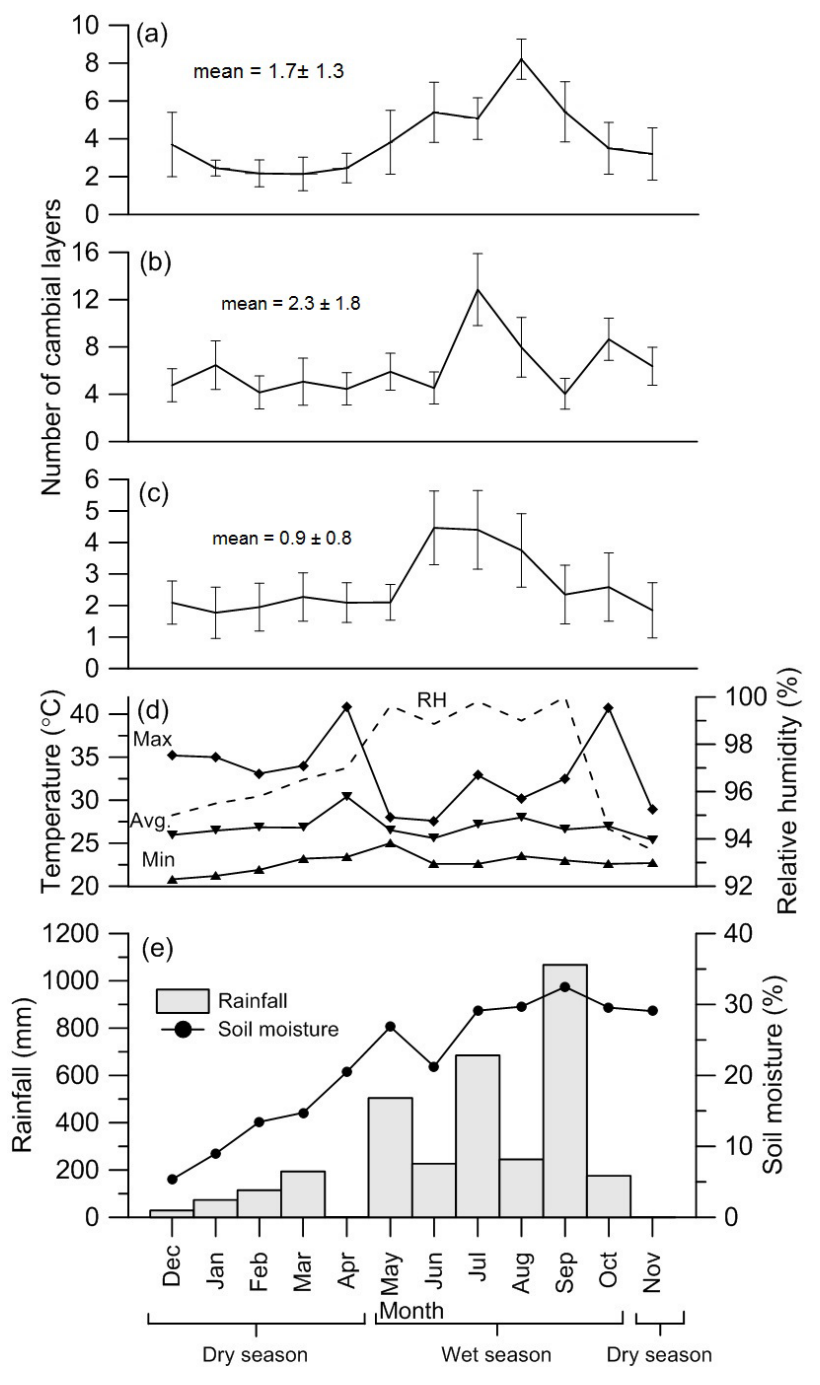

Figure 2 Mean tangential layers of cambial cells $( \pm$ SE) of (a) Tetrameles nudiflora, (b) Hopea pierrei and (c) Cleidion spiciflorum in relation to $(\mathrm{d})$ temperature and relative humidity, (e) rainfall and soil moisture, from 2011 to 2012 
Table 1 Pearson correlation coefficients and the level of the p values between growth parameters and environmental variables

\begin{tabular}{lccccccc}
\hline Tree species & Growth parameter & $\mathrm{R}$ & $\mathrm{T}_{\mathrm{MIN}}$ & $\mathrm{T}_{\mathrm{AV}}$ & $\mathrm{T}_{\mathrm{MAX}}$ & $\mathrm{SM}$ & $\mathrm{RH}$ \\
\hline Tetrameles nudiflora & $\mathrm{CL}$ & 0.245 & 0.012 & 0.089 & -0.101 & 0.416 & $0.645^{* *}$ \\
& $\mathrm{CRG}$ & -0.058 & -0.001 & 0.128 & 0.582 & $0.708^{*}$ & $-0.637^{*}$ \\
& & & & & & & \\
Hopea pierrei & $\mathrm{CL}$ & 0.005 & 0.046 & 0.448 & 0.206 & 0.250 & 0.317 \\
& $\mathrm{CRG}$ & -0.140 & 0.418 & $0.819^{* *}$ & 0.333 & 0.223 & 0.001 \\
Cleidion spiciflorum & $\mathrm{CL}$ & 0.059 & 0.084 & 0.321 & -0.127 & 0.120 & 0.436 \\
& $\mathrm{CRG}$ & -0.512 & 0.568 & -0.339 & -0.550 & -0.263 & -0.344 \\
\hline
\end{tabular}

$\mathrm{CL}=$ cambial layers, $\mathrm{CRG}=$ cumulative radial growth, $\mathrm{R}=$ total rainfall, $\mathrm{T}_{\mathrm{MIN}}, \mathrm{T}_{\mathrm{AV}}$ and $\mathrm{T}_{\mathrm{MAX}}=$ minimum, mean and maximum temperatures respectively, $\mathrm{SM}=$ soil moisture, $\mathrm{RH}=$ air relative humidity; $* *<0.05$ and $*<0.01$

activity for T. nudiflora for the wet season was almost double that of the early dry season from December 2011 to May 2012 (5.1 \pm 1.4 versus $2.6 \pm 0.9)$, possibly indicating a greater responsiveness to seasonal variation in the environment than in $H$. pierrei. Mean cambial activity of $H$. pierrei across the early dry season $(5.0 \pm 1.6)$ was double that of T. nudiflora and $C$. spiciflorum $(2.6 \pm 0.9$ and $2.0 \pm 0.7$ respectively), which again indicated that growth in the latter two species might be limited by environmental variation to a greater degree than $H$. pierrei. The lowest cambial activities of $T$. nudiflora (2.1 \pm 0.9 , end-March) and C. spiciflorum (1.8 \pm 0.8 , end-February) during the dry season could be considered the baseline for dormancy and these species appeared to enter a period of dormancy with little to no growth registered for months. In contrast, monthly cambial activity for $H$. pierrei rarely fell below 4.0 and the varying cambial layer counts recorded month by month during the dry season indicated that this species did not enter dormancy.

The results of our study are in agreement with those of Pumijumnong and Buajan (2013) showing year-round cambial activity for five tropical tree species studied in central Thailand. In their study, cambial activity for T. nudiflora also peaked a few months after the start of the wet season but this peak (median value $=11.7$ cambial layers counted) was in June whereas peak cambial activity for T. nudiflora in our study was in August. Additionally, our findings on dry season dormancy of T. nudiflora and C. spiciflorum concur with previous reports of cambial dormancy for A. excelsa in Malaysia (Wang et al. 2013) and A. indica in India (Rao \& Rajput 2001b) which was associated with low rainfall in the dry season. It is noted that cambial activity of $C$. euphyllum in Thailand was reported to correlate negatively with temperature in the wet season (Pumijumnong \& Buajan 2013) while cambial activity of Dillenia indica correlated strongly with temperature and not with rainfall in India (Venugopal \& Liangkuwang 2007). Temperature and precipitation seem to be the major triggers in subtropical and tropical forest respectively (Oliveira et al. 2009).

\section{Seasonal radial increment}

As a whole, rainfall and relative humidity showed negative associations with radial increment rates for the three species (Figure 6) but these associations were not significant except for $T$. nudiflora where radial increment had significant negative correlation with relative humidity $(\mathrm{r}=-0.637, \mathrm{p}<0.05$, Table 1$)$. The radial increment of T. nudiflora also had significant positive correlation with soil moisture $(\mathrm{r}=0.708$, $\mathrm{p}<0.05)$ while that of $H$. pierrei was positively correlated with average temperature $(r=0.819$, $\mathrm{p}<0.01)$.

Radial increment recorded over the 6 months was highest for $H$. pierrei (mean $1072.8 \pm 0.1 \mu \mathrm{m}$ ), which was four times that of T. nudiflora (317.6 $\pm 0.1 \mu \mathrm{m})$, which in turn was four times greater than that of $C$. spiciflorum $(93.8 \pm 0.2 \mu \mathrm{m}$, Figure 6). Comparatively, cambial layer counts for $H$. pierrei $(2.3 \pm 1.8$, Figure 2$)$ was higher than that of T. nudiflora $(1.7 \pm 1.3)$, which in turn was double that of C. spiciflorum $(0.9 \pm 0.8)$, indicating that the magnitude of radial increment was greater than that of cambial layer growth. 

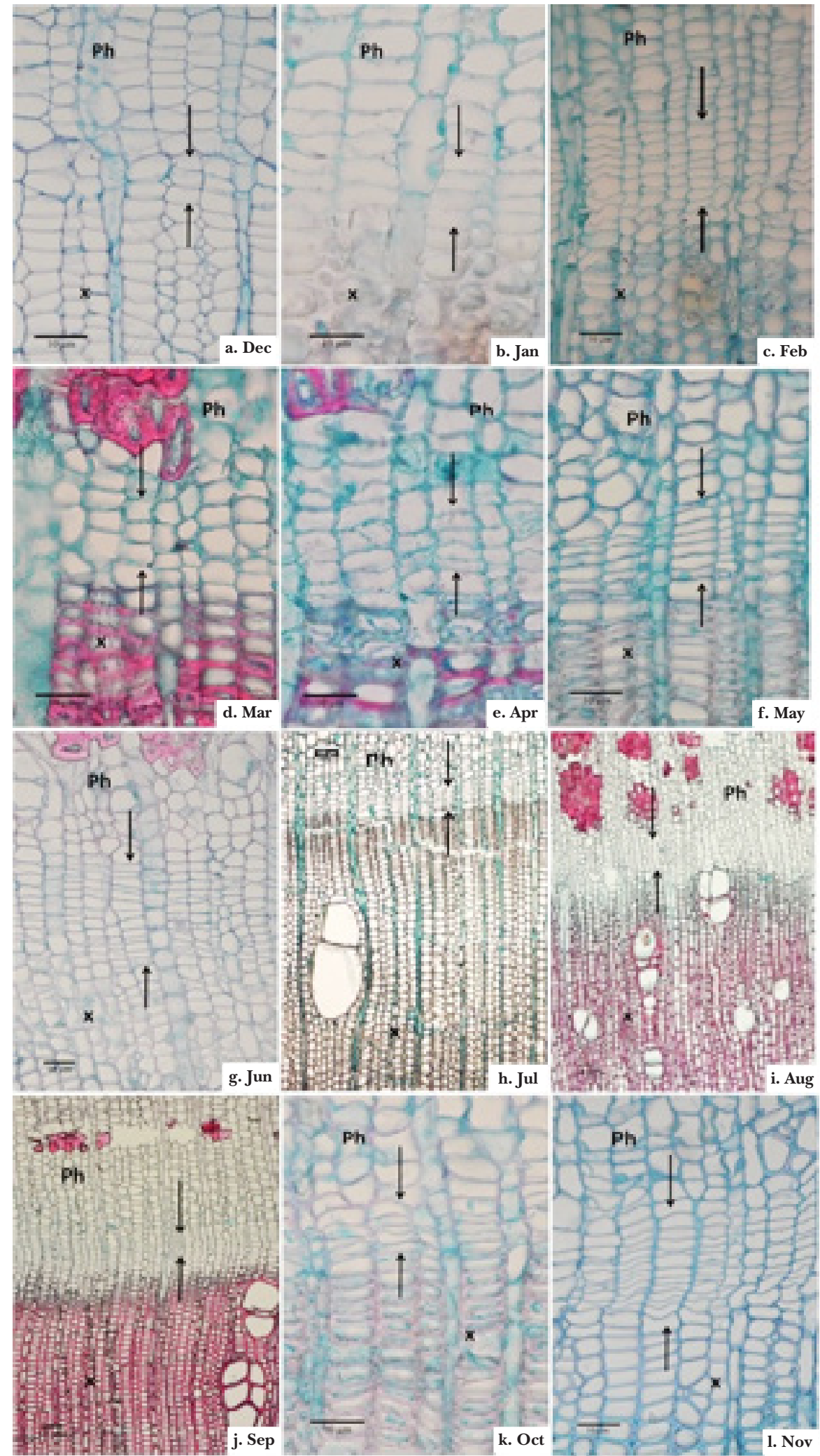

Figure 3 Transverse sections of Tetrameles nudiflora showing cambial activity from December 2011 to November 2012; black arrows indicate cambial zone, $\mathrm{Ph}=$ phloem, $\mathrm{X}=$ xylem; scale bar $=10 \mu \mathrm{m}$ for plates a-g and $\mathrm{k}-\mathrm{l}$, scale bar $=100 \mu \mathrm{m}$ for plates $\mathrm{h}-\mathrm{j}$ 

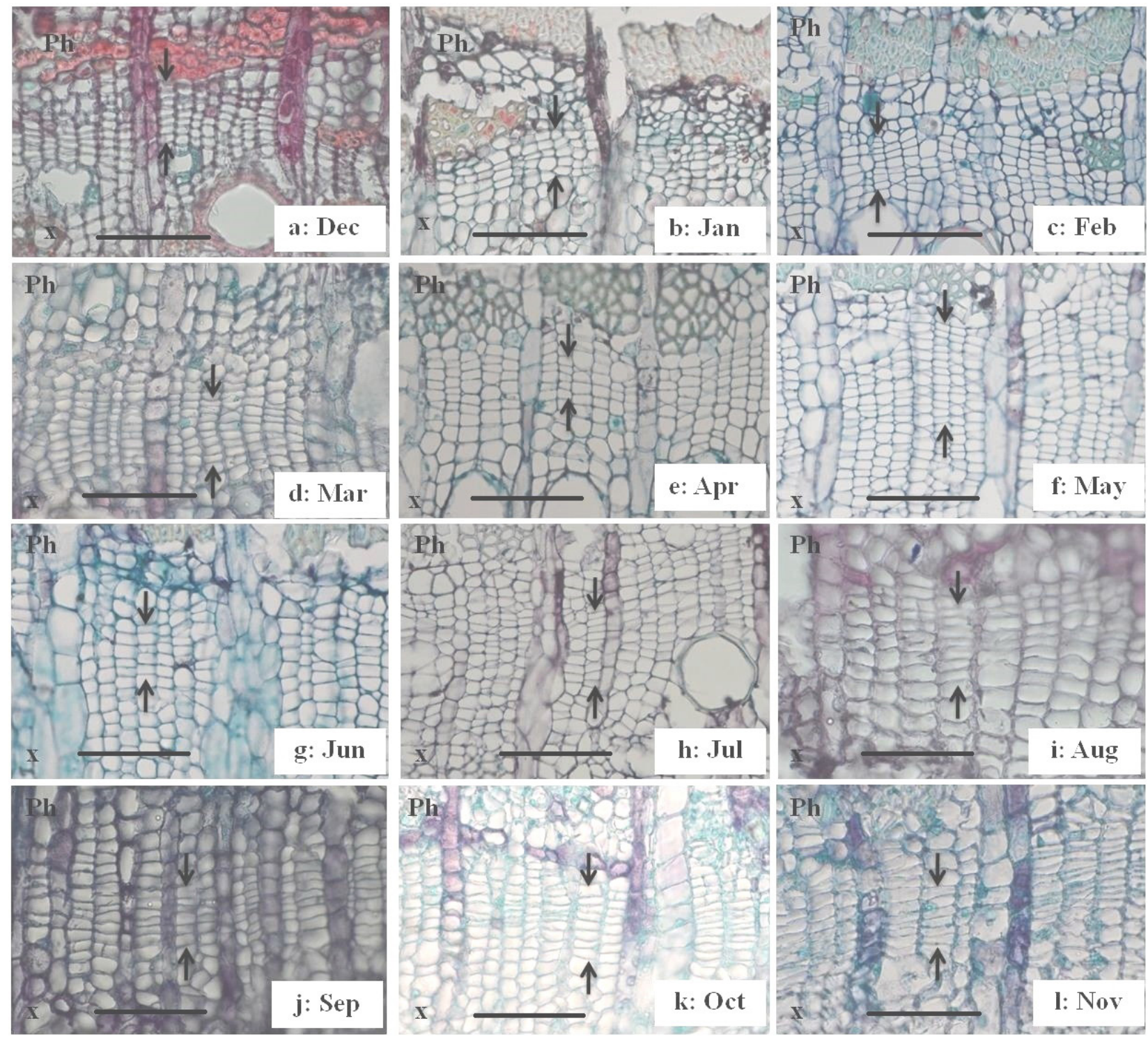

Figure 4 Transverse sections of Hopea pierrei showing cambial activity from December 2011 to November 2012; black arrows indicate cambial zone, $\mathrm{Ph}=$ phloem, $\mathrm{X}=$ xylem; scale bar $=60 \mu \mathrm{m}$

The season means of radial increment for the three species during the wet season were at least double that recorded for the dry season. While cambial dormancy in T. nudiflora and $C$. spiciflorum could be recognised by consecutive months of unchanging cambial layer counts during the dry season, this dormancy was not reflected in radial increment or decrement.

\section{Diurnal radial variation}

Changes in tree diameter comprise addition and enlargement of cambial derivatives and reversible changes in size due to hydration and temperature, which explain more than $90 \%$ of stem radial fluctuations (Zweifel et al. 2014). In the three species, radial increment was greater on wet days than on dry days, with the pattern of diurnal variation for dry days appearing to parallel that for wet days (Figure 7). All three species appeared to follow the typical pattern of tree stem shrinkage in the afternoon with stem radii falling to their lowest at around 2.30 p.m. From that point stem radii increased-the increase tending to be steeper on abundant rainfall days than on dry days-reaching maximum stem radii at $8.30 \mathrm{a} . \mathrm{m}$. the next morning. Shrinkage followed until about 2.30 p.m. and on dry days 

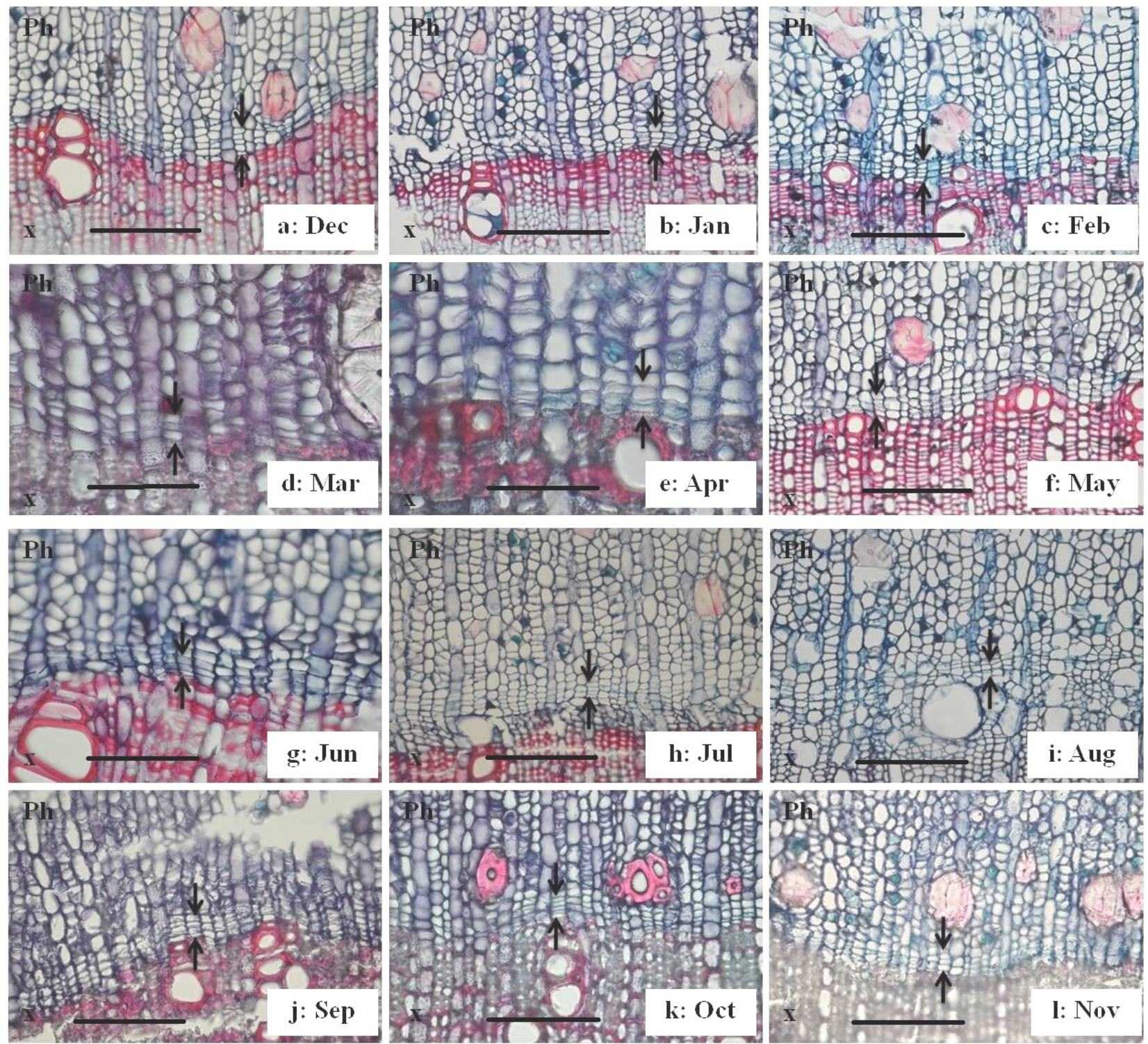

Figure 5 Transverse sections of Cleidion spiciflorum showing cambial activity from December 2011 to November 2012; black arrows indicate the cambial zone, $\mathrm{Ph}=$ phloem, $\mathrm{X}=\mathrm{xylem}$; scale bar $=60 \mu \mathrm{m}$

it fell to or below the previous day's low, but on wet days it fell no lower, thus, resulting in net increment (irreversible growth) in that diurnal cycle. Stem shrinkage during the day is due to net water loss by transpiration, while rehydration and expansion occurs at night (Kozlowski 1971). Since shrinking and swelling can mask tissue growth, radial variation as measured by dendrometers may not approximate cambial growth (Kozlowski 1971).

\section{CONCLUSIONS}

Our preliminary study of cambial activity of three species growing in the tropical monsoon rainforest of Chang Island revealed that growth, which was measured by the number of cambial layers, was year-round and much higher in the wet season than in the dry season. Our results also showed that while radial variation measured by electronic dendrometers generally followed 


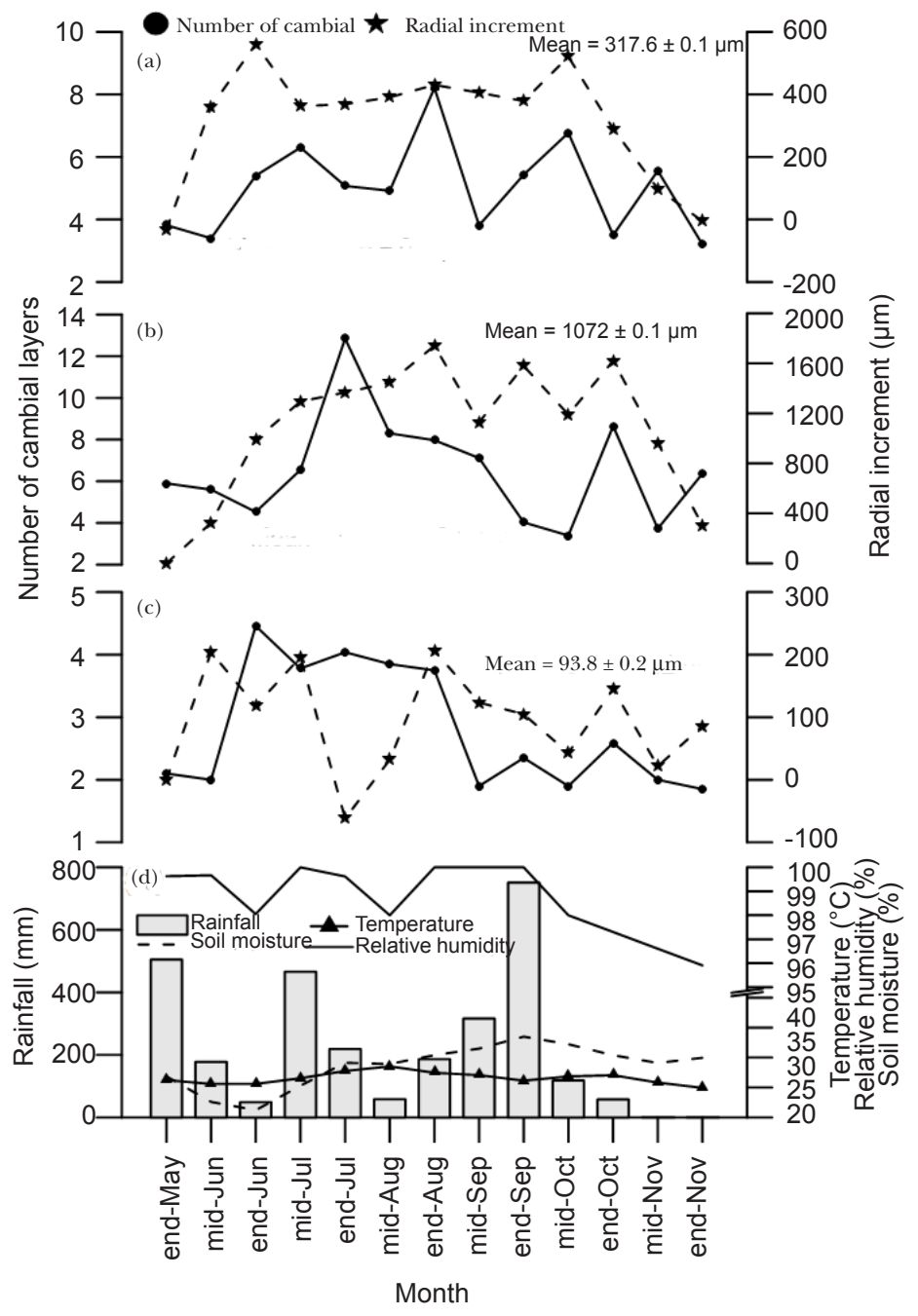

Figure 6 Number of cambial layers and radial increment $(\mu \mathrm{m})$ of (a) Tetrameles nudiflora, (b) Hopea pierrei, (c) Cleidion spiciflorum in relation to (d) temperature, rainfall, soil moisture and relative humidity from May to November 2012

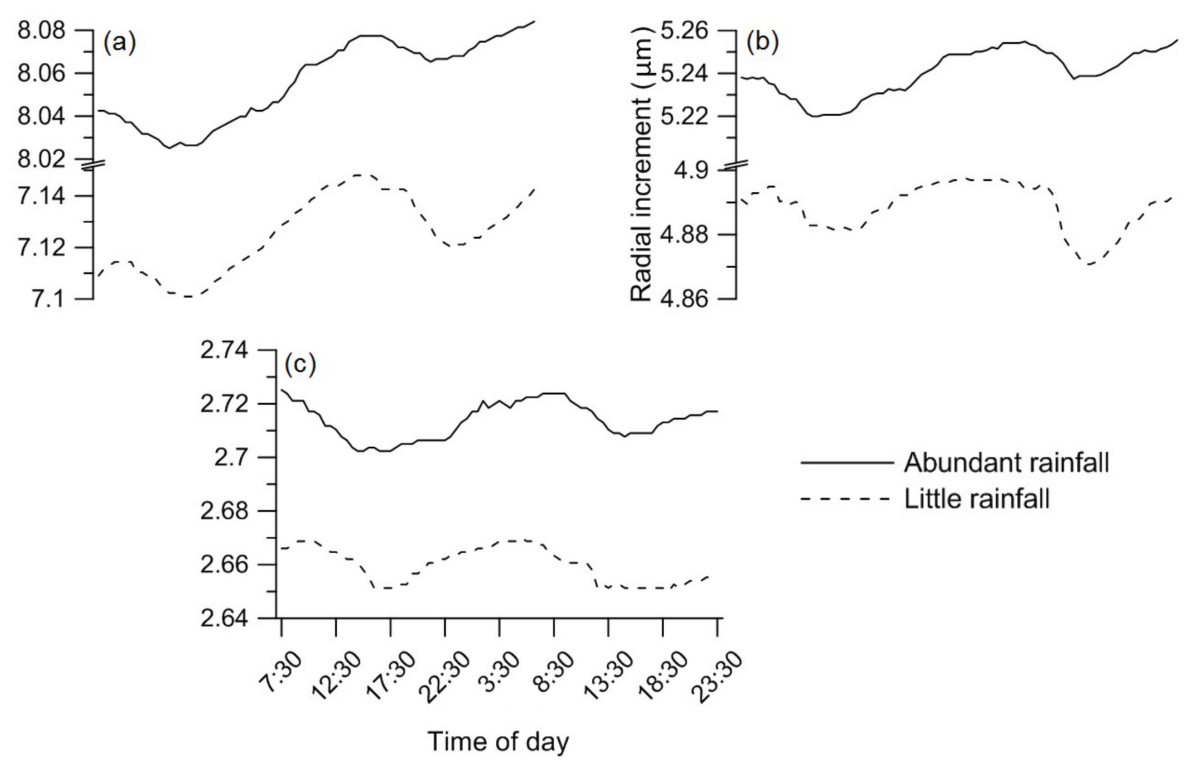

Figure 7 Hourly radial variation $(\mu \mathrm{m})$ over 24 hours in relation to little and abundant rainfall days in September 2012, for (a) Hopea pierrei, (b) Tetrameles nudiflora, (c) Cleidion spiciflorum 
that of cambial activity, radial increment did not correlate significantly with cambial activity. Longterm monitoring of cambial activity and radial variation is needed to determine the factors driving growth in these species of interest.

\section{ACKNOWLEDGEMENTS}

We would like to thank the staff at Koh Chang National Park who facilitated data collection. This study was financially supported by Mahidol University. We are deeply thankful to Stewart $\mathrm{TN}$ for proofreading early drafts of this manuscript.

\section{REFERENGES}

Bräuning A, Homeier J, Cueva E, Beck E \& Günter S. 2008. Growth dynamics of trees in tropical mountain ecosystems. Pp 291-302 in Beck E et al. (eds) Gradients in a Tropical Mountain Ecosystem of Ecuador. Ecological Studies (Analysis and Synthesis). Volume 198. Springer, Berlin, Heidelberg. https://doi. org/10.1007/978-3-540-73526-7_28.

Clark DA \& Clark DB. 1994. Climate-induced annual variation in canopy tree growth in a Costa Rican tropical rain forest. Journal of Ecology 865-872. https://doi.org/10.2307/2261450.

Deslauriers A, Morin H, Urbinati C \& Carrer M. 2003. Daily weather response of balsam fir (Abies balsamea (L.) Mill.) stem radius increment from dendrometer analysis in the boreal forests of Québec (Canada). Trees 17: 477-484. https:/ /doi.org/10.1007/s00468003-0260-4.

Downes G, Beadle C \& Worledge D. 1999. Daily stem growth patterns in irrigated Eucalyptus globulus and E. nitens in relation to climate. Trees-Structure and Function 14: 102-111. https://doi.org/10.1007/PL00009752.

Gardner S, Sidisunthorn P \& Anusarnsunthorn V. 2000. A Field Guide to Forest Trees of northern Thailand. Kobfai Publishing Project, Bangkok.

Holtham KA \& Slepecky NB. 1995. A simplified method for obtaining 0.5-microns sections of small tissue specimens embedded in PEG. Journal of Histochemistry E Cytochemistry 43: 637-643. https:/ / doi.org/10.1177/43.6.7769235.

IUCN. 2012. IUCN Red List of Threatened Species. Threatened Species. Summary Statistics. https:// www.iucnredlist.org/resources/summary-statistics.

Kozlowski TT. 1971. Cambial Growth, Root Growth, and Reproductive Growth. Academic Press, New York.

Krepkowski J, Bräuning A \& Gebrekirstos A. 2012. Growth dynamics and potential for cross-dating and multicentury climate reconstruction of Podocarpus falcatus in Ethiopia. Dendrochronologia 30: 257-265. https:// doi.org/10.1016/j.dendro.2012.01.001.

Menkham S. 2001. Phytochemical Study of Cleidion spiciflorum (Burm. f.) Merr. Leaves. Chulalongkorn University, Bangkok.
Naengchomnong W, Pinho PM, Kijjoa A et al. 2006. Clerodanes and other constituents of Cleidion spiciflorum. Phytochemistry 67: 1029-1033. https://doi. org/10.1016/j.phytochem.2006.03.024.

Oliveira JM, Santarosa E, Pillar VD \& Roig FA. 2009. Seasonal cambium activity in the subtropical rain forest tree Araucaria angustifolia. Trees 23: 107-115. DOI 10.1007/s00468-008-0259-y.

Prasad PRC, Reddy CS, Raza S \& Dutt C. 2008. Folklore medicinal plants of north Andaman Islands, India. Fitoterapia 79: 458-464. https://doi.org/10.1016/j. fitote.2008.03.007.

PRIYA P \& BHAT K. 1999. Influence of rainfall, irrigation and age on the growth periodicity and wood structure in teak (Tectona grandis). IAWA Journal 20: 181-192. https://doi.org/10.1163/2294193290000678 .

Pumiumnong N \& Buajan S. 2013. Seasonal cambial activity of five tropical tree species in central Thailand. Trees 27: 409-417. https://doi.org/10.1007/s00468-0120794-4.

Pumijumnong N \& Payomrat P. 2013. The effective ecological factors and vegetation at Koh Chang island, Trat province, Thailand. Open Journal of Forestry 3: 41-48. http://dx.doi.org/10.4236/ojf.2013.31007.

RaO K \& DAVE Y. 1981. Seasonal variations in the cambial anatomy of Tectona grandis (Verbenaceae). Nordic Journal of Botany 1: 535-542. https://doi. org/10.1111/j.1756-1051.1981.tb00719.x.

RaO K \& Rajput KS. 1999. Seasonal behaviour of vascular cambium in teak (Tectona grandis) growing in moist deciduous and dry deciduous forests. IAWA Journal 20: 85-93. https://doi.org/10.1163/2294193290001553.

RAO K \& RAJPUT KS. 2001a. Xylem structure and annual rhythm of development in the twigs of Acacia nilotica (L.) Del. growing in different forests of Gujarat state (India). Phyton 41: 1-12.

Rao KS \& RAJPUt KS. 2001b. Relationship between seasonal cambial activity, development of xylem and phenology in Azadirachta indica growing in different forests of Gujarat State. Annals of Forest Science 58: 691-698. https://doi.org/10.1051/ forest:2001156.

Shimamoto CY, Botosso PC, Amano E \& Marques MC. 2016. Stem growth rhythms in trees of a tropical rainforest in Southern Brazil. Trees 30: 99-111. https://doi. org/10.1007/s00468-015-1279-z.

Thai Meteorological Department. 2010. Data of climate between the years 1990-2009 at Khlong Yai Station, Trat Province.

VENUGOPAL N \& LiAngKuWANG M. 2007. Cambial activity and annual rhythm of xylem production of elephant apple tree (Dillenia indica Linn.) in relation to phenology and climatic factor growing in subtropical wet forest of northeast India. Trees 21: 101-110. https://doi.org/10.1007/s00468-0060101-3.

Wang K, Nobuchi T, Azim AA \& SAhri M. 2013. Seasonal variations in cambial anatomy of plantation-grown Azadirachta excelsa. Journal of Tropical Forest Science 25: 111-117. 
Wang KH \& Hamzah MZ. 2018. Different cambial activities in response to climatic factors of three Malaysian rainforest Shorea species with different stem diameters. Trees 32: 1519-1530. https://doi. org/10.1007/s00468-018-1730-z.
Zweifel R, Drew DM, Schweingruber F \& Downes GM. 2014. Xylem as the main origin of stem radius changes in Eucalyptus. Functional Plant Biology 41: 520-534. https://dx.doi.org/10.1071/FP13240. 